\title{
ANALISIS KUALITAS PRODUK DAN HARGA TERHADAP KEPUASAN PELANGGAN DI PT. ANDRIYANI JAYA ABADI (PAM) (Studi Kasus Di RW 2 Kelurahan Klamasen Kabupaten Sorong)
}

\author{
1Paradilla Teana, ${ }^{2 *}$ Ahmad Jamil \\ Universitas Muhammadiyah Sorong, Papua Barat, Indonesia \\ *ahmadjamil@um-sorong.ac.id
}

\begin{abstract}
Abstrak
Penelitian ini berjudul "Analisis Kualitas Produk Dan Harga Terhadap Kepuasan Pelanggan Di PT. Andriyani Jaya Abadi (PAM) Kabupaten Sorong”, dengan menggunakan dua variabel yaitu Kualitas Produk dan Harga. Penelitian ini merupakan penelitian deskriptif korelasi dengan pendekatan kuantitatif dan menggunakan uji validitas, uji reliabilitas, uji asumsi klasik (uji normalitas, uji linearitas, uji multikolinearitas, uji heterokedastisitas), uji regresi linear berganda, uji parsial (uji t), dan uji koefisien determinasi $\left(\mathrm{R}^{2}\right)$. Populasi pada penelitian ini adalah pelanggan PT. Andriyani Jaya Abadi (PAM) Kabupaten Sorong yang bertempat tinggal di RW 2 Kelurahan Klamasen Kabupaten Sorong. Teknik pengambilan sampel menggunakan teknik purposive sampling dengan jumlah sampel 80 orang. Teknik pengumpulan data menggunakan wawancara, kuesioner, observasi, studi pustaka, dan dokumentasi. Teknik analisis data yang digunakan adalah analisis deskriptif dan regresi linier berganda. Hasil penelitian secara parsial menunjukan bahwa kualitas produk berpengaruh terhadap kepuasan pelanggan dan harga berpengaruh terhadap kepuasan pelanggan pada PT. Andriyani Jaya Abadi (PAM) Kabupaten Sorong sebesar 70,01\%.
\end{abstract}

Kata Kunci: Kualitas Produk, Harga, Kepuasan Pelanggan

Abstract

This research entitled "Analysis of Product Quality and Price On Customer Satisfaction In PT. Andriyani Jaya Abadi (PAM) Sorong District, by two variables namely product quality and price. This research is a descriptive correlation study with a quantitative approach and uses a validity test, a reliability test, classical assumption test (normality test, linearity test, multicolinearity test, heterokedasticity test), multi linear regression test, partial test ( $t$ test), and coefficient of determination test. The population in this study are customers of PT. Andriyani Jaya Abadi (PAM), Sorong Regency, who live in RW 2, Klamasen, Sorong Regency. The sampling technique used purposive sampling technique with a sample size of 80 people. Data collection techniques using interviews, questionnaires, observations, literature study, and documentation. Data analysis techniques used are descriptive analysis and multiple linear regression. Partial research results indicate that product quality affects customer satisfaction and price affects customer satisfaction at PT. Andriyani Jaya Abadi (PAM) Sorong District by $70,01 \%$.

Keywords: Product Quality, Price, Customer satisfaction

\section{PENDAHULUAN}

Perusahaan saat ini berhadapan dengan kondisi persaingan tetapi juga berhadapan dengan pelanggan yang keinginan dan kebutuhannya akan terpenuhi, sehingga perusahaan sangat mengharapkan memiliki pelanggan yang loyal terhadap produk atau jasa yang ditawarkan, salah satunya air sumber daya alam yang memiliki fungsi bagi kehidupan manusia.
PT. Andriyani Jaya Abadi (PAM) adalah salah satu perusahaan pengelola air bersih milik daerah yang diberikan kepercayaanDinas PU (Pekerjaan Umum) untuk bekerjasama sebagai pengelola distribusi air bersih bagi masyarakat umum di Kabupaten Sorong. PT. Andriyani Jaya Abadi (PAM) beralamat di Jl. Cempedak No. 52 Malawili Aimas, Kabupaten Sorong.

Assauri (2012: 11) kepuasan pelanggan merupakan suatu indikator ke 
depan akan keberhasilan bisnis perusahaan, yang mengukur bagaimana baiknya tanggapan pelanggan terhadap masa depan bisnis perusahaan. Dalam mempengaruhi kepuasan pelanggan terdapat beberapa faktor yang mempengaruhi tinggi rendahnya tingkat kepuasan pelanggan.Faktor faktor tersebut.

Salah satu faktor yang dapat mempengaruhi kepuasan pelanggan adalah kualitas produk. Menurut Kotler dan Amstrong (2006:225) kualitas produk adalah kemampuan suatu produk untuk menjalankan fungsi-fungsinya yang meliputi: daya tahan, kehandalan, ketelitian yang dihasilkan, kemudahan dioperasikan dan diperbaiki, dan nilai yang bermanfaat dari atribut lain secara keseluruhan.Pada wilayah RW 2 Kelurahan Klamasen Kabupaten Sorong, kualitas airnya kurang baik sehingga mempengaruhi kepuasan pelanggan. Selanjutnya harga merupakan salah satu faktor yang mempengaruhi kepuasan pelanggan.Menurut Kotler dan Amstrong (1996) mengatakan bahwa harga (price) adalah jumlah uang yang ditagihkan untuk suatu produk dan jasa, atau jumlah dari nilai yang dipertukarkan konsumen untuk manfaat memiliki atau menggunakan produk dan jasa. Terjadinya kenaikan harga pasang air PAM dan adanya kerusakan meteran air sehingga terjadi lonjakan harga.

\section{TINJAUAN PUSTAKA}

1. Manajemen Pemasaran

Menurut Kotler dan Amstrong (2006:16) dikutip dari jurnal (Manampiring \& Trang, 2016) manajamen pemasaran adalah analisis, perencanaan, implementasi dan pengendalian program yang dirancang untuk menciptakan, membangun dan mempertahankan pertukaran yang menguntungkan dengan pembeli sasaran demi mencapai tujuan organisasi.

2. Kualitas Produk

Menurut (Kotler \& Keller, 2009: 299) kemampuan suatu produk untuk melakukan fungsi - fungsinya yang meliputi daya tahan, keandalan, ketepatan, kemudahan, operasi dan perbaikan serta atribut lainnya.

3. Harga

Menurut Kotler dan Amstrong (2001:73) mengatakan bahwa harga (price) adalah sejumlah uang yang harus dibayar oleh pelanggan untuk memperoleh produk (Sari, 2016).

4. Kepuasaan Pelanggan

Menurut Assauri (2012: 11) kepuasan pelanggan merupakan suatu indikator ke depan akan keberhasilan bisnis perusahaan, yang mengukur bagaimana baiknya tanggapan pelanggan terhadap masa depan bisnis perusahaan.

\section{METODE}

Penelitian ini menggunakan pendekatan kuantitatif dan metode yang digunakan yaitu metode deskriptif dan studi korelasi. Sedangkan metode korelasi yang digunakan adalah teknik korelasi pearson. Populasi adalah pelanggan pengguna air PAM yang bertempat tinggal di RW 2 Kelurahan Klamasen, Kabupaten Sorong dengan jumlah 100 pelanggan. Sampel yang diambil peneliti adalah sebagian dari populasi dengan menggunakan rumus slovin didapatkan 80 responden. Teknik penarikan sampel menggunakan teknik purposive sampling. Peneliti menggunakan teknik pengumpulan data berupa wawancara, kuesioner, observasi, studi pustaka, dan dokumentasi.

Tujuan dari analisis data ini adalah untuk mengetahui besarnya pengaruh masing-masing variabel bebas terhadap variabel terikatnya, adapun uji yang digunakan adalah uji statistik deskriptif, analisis regresi berganda, uji instrumen penelitian, uji asumsi klasik, uji $t$, uji koefisien determinasi ( $\mathrm{R}^{2}$ ).

\section{HASIL DAN PEMBAHASAN}

1. Pembahasan Hasil Penelitian

a. Pengaruh produk terhadap keputusan pembelian vape di D'mom cafe Sorong. 
Berdasarkan pengolahan data menggunakan regresi berganda dengan membandingkan nilai signifikan yang harus lebih kecil dari $0,05(0,000>0,05)$ dan nilai $t$ hitung yang harus lebih besar dari $\mathrm{t}$ tabel $(0,4,492>(2,02619)$ maka produk berpengaruh positif dan tidak signifikan terhadap keputusan pembelian, begitu juga dengan menggunakan korelasi produk memiliki pengaruh terhadap keputusan pembelian vape di D'mom cafe Sorong.

b. Pengaruh promosi terhadap keputusan pembelian vape di D'mom cafe Sorong.

Berdasarkan pengolahan data menggunakan regresi berganda dengan membandingkan nilai signifikan yang harus lebih kecil dari $0,05(0,000>0,05)$ dan nilai t hitung yang harus lebih besar dari $\mathrm{t}$ tabel $(0,4,934>(2,02619)$ maka promosi berpengaruh positif dan tidak signifikan terhadap keputusan pembelian, begitu juga dengan menggunakan korelasi promosi memiliki pengaruh terhadap keputusan pembelian vape di D'mom cafe Sorong.

\section{PENUTUP}

\section{Kesimpulan}

Berdasarkan hasil penelitian dan pembahasan, maka dapat ditarik beberapa kesimpulan sebagai berikut:

1. Uji koefisien determinasi ( $\mathrm{R}$ square) didapatkan angka sebesar 0,701 sama dengan $70,1 \%$. Angka tersebut mengandung arti bahwa faktor kualitas produk dan faktor harga berpengaruh terhadap kepuasan pelanggan sebesar $70,1 \%$.

2. Kualitas produk berpengaruh positif dan signifikan terhadap kepuasan pelanggan di PT. Andriyani Jaya Abadi (PAM) Kabupaten Sorong. Hal ini dibuktikan dengan terjawabnya hipotesis pertama, dimana hipotesis kualitas produk $(\mathrm{X} 1)=$ 9,661 dengan sig. $=0,000<0,05$.
3. Harga berpengaruh positif dan signifikan terhadap kepuasan pelanggan di PT. Andriyani Jaya Abadi (PAM) Kabupaten Sorong. Hal ini dibuktikan dengan terjawabnya hipotesis kedua, dimana hipotesis harga $(X 2)=9,362$ dengan sig. $=0,000<0,05$.

\section{Saran}

Berdasarkan hasil analisis, maka peneliti memberikan beberapa saran sebagi berikut:

1. Bagi Peneliti Selanjutnya

Peneliti selanjutnya dapat mengembangkan penelitian ini dengan meneliti faktor lain. Dari hasil uji koefisien determinasi $\left(\mathrm{R}^{2}\right)$ didapatkan nilai pengaruh kualitas produk dan harga terhadap kepuasan pelanggan sebesar $70,1 \%$ sehingga $100 \%-70,1 \%=$ $29,9 \%$ dipengaruhi variabel lain diluar penelitian ini. Maka penelitian selanjutnya disarankan meneliti variabel yang ada diluar penelitian ini seperti kualitas pelayanan, faktor emosional, dan kemudahan mendapatkan produk.

2. Bagi PT. Andriyani Jaya Abadi (PAM) Kabupaten Sorong

1) Berdasarkan hasil penelitian menunjukkan bahwa kualitas produk berpengaruh positif dan signifikan terhadap kepuasan pelanggan. Adapun indikator kualitas pelanggan dapat dijelaskan sebagai berikut:

a. Kualitas yang dipersepsikan

Pada pernyataan indikator kualitas yang persepsikan didalam pengujian validitas, didapatkan skor terendah sehingga indikator kualitas yang dipersepsikan mempunyai nilai rendah.Adapun saranyang diberikan peneliti untuk perusahaan ialah memperbaiki hubugan dengan pelanggannya dengan cara meningkatkan kualitas produknya, sehingga persepsi pelanggan terhadap produknya menjadi positif.

b. Manfaat Produk

Pada pernyataan indikator manfaat produk didalam 
pengujian validitas, didapatkan skor tertinggi sehingga indikator manfaat produk mempunyai nilai tinggi.Adapun saran yang diberikan peneliti untuk perusahaan ialah tetap mempertahankan kualitas produknya, karena manfaat air sangat berperan penting bagi pemenuhan kebutuhan pelanggan.

c. Daya Tahan Produk

Pada pernyataan indikator daya tahan produk didalam pengujian validitas, didapatkan skor tertinggi setelah indikator manfaat produk sehingga indikator daya tahan produk mempunyai nilai sedang. Adapun saran yang diberikan peneliti untuk perusahaan ialah meningkatkan kembali kualitas produknya dengan selalu menjaga kebersihan air PAM.

2) Berdasarkan hasil penelitian menunjukkan bahwa harga berpengaruh positif dan signifikan terhadap kepuasan pelanggan. Adapun indikator harga dapat dijelaskan sebagai berikut:

a. Kesesuaian harga dengan produk

Pada pernyataan indikator kesesuaian harga dengan produk didalam pengujian validitas, didapatkan skor tertinggi sehingga indikator kesesuaian harga dengan produk mempunyai nilai tinggi.Adapun saran yang diberikan peneliti untuk perusahaan ialah tetap mempertahankan harga yang telah ditetapkan, karena harga merupakan salah satu faktor penentu kepuasan pelanggan.

b. Potongan harga

Pada pernyataan indikator potongan harga didalam pengujian validitas, didapatkan skor tertinggi setelah indikator kesesuaian harga dengan produk sehingga indikator potongan harga mempunyai nilai sedang. Adapun saran yang diberikan peneliti untuk perusahaan ialah mengadakan lagi promo harga untuk pasang baru air PAM, agar dapat meningkatkan jumlah pelanggan.

c. Harga yang dipersepsikan

Pada pernyataan indikator harga yang dipersepsikan didalam pengujian validitas, didapatkan skor terendah sehingga indikator harga yang dipersepsikan mempunyai nilai rendah. Adapun saran yang diberikan peneliti untuk perusahaan ialah memperbaiki hubugan dengan pelanggannya dengan cara selalu menjaga kestabilan harga, sehingga persepsi pelanggan terhadap harga air PAM menjadi positif.

\section{DAFTAR PUSTAKA}

Akila.(2017). Pengaruh Insentif Dan Pengawasan Terhadap Produktivitas Kerja Karyawan Pada CV. Vassel Palembang, 40.

Amirullah, Hardjanto, Imam. (2005). Pengantar Bisnis. Graha Ilmu: Yogyakarta.

Assauri, S. (2012).Strategic Marketing: Sustaining Lifetine Customer Value. Jakarta:Rajawali Pers.

Haque, M. G., Nurjaya, N., Affandi, A., Erlangga, H., \& Sunarsi, D. (2021). Micro Financial Sharia Non-bank Strategic Analysis: a Study at BMT Beringharjo, Yogyakarta. Budapest International Research and Critics Institute (BIRCI-Journal): Humanities and Social Sciences, 4(2), 1677-1686.

Isdianto, Oki dan Kurniawan, Soni.(2017) Pengaruh Praktek MSDM Strategik Dan Kinerja Karyawan Terhadap Kinerja Perusahaan Persewaan Alat Pesta OR, 59.

Jasmani, J., Sutiman, S., \& Sunarsi, D. (2020). Analysis of the Effect of Prices, Promotions and Products on Purchase Interest Impacts on Consumer Satisfaction of VIVO Brand Mobile 
Phones in South Tangerang Region. Jurnal Ad'ministrare, 7(1), 73-82.

Kadarusman, Y., \& Sunarsi, D. (2020). Pengaruh Strategi Penetapan Harga Terhadap Peningkatan Jumlah Siswa Pada SMK PGRI Balaraja. IS (Jurnal Sekolah), 4(3), 213-221.

Kotler, Philip dan Amstrong, Grey.(2004). Dasar-Dasar Pemasaran. Penerjemah Alexander Sindoro. PT. Indeks: Jakarta, Edisi ke-9, Jilid 1 hal. 7.

Kotler, Philip dan Keller, Lane Kevin. (2008). Manajemen Pemasaran, Edisi Ketiga Belas Jilid 1.Erlangga, hal. 5.

Kotler, Philip dan Keller, Lane Kevin. (2009). Manajemen Pemasaran Edisi 13 Jilid 1. Erlangga: Jakarta.

Maddinsyah, A., Hidayat, D., Juhaeri, J., Susanto, D., \& Sunarsi, D. (2020). Desain Formulasi Dan Implementasi Bisnis Strategik Dengan Pendekatan Business Model Canvas (BMC) Terintegrasi Kerangka Integrated Performance Management System (IPMS) Pada Koperasi Asperindo. Inovasi, 7(2), 67-76.

Manampiring, Andrew F dan Trang, Irvan.(2016). Pengaruh Produk, Harga, Promosi Dan Tempat Terhadap Keputusan Pembelian Mobil Di PT. Astra Internasional Tbk Malalayang, 2.

Nurjaya, N., Sunarsi, D., Effendy, A. A., Teriyan, A., \& Gunartin, G. (2021).
Pengaruh Etos Kerja Dan Disiplin Kerja Terhadap Kinerja Pegawai Pada Dinas Kehutanan Dan Perkebunan Kota Bogor. JENIUS (Jurnal Ilmiah Manajemen Sumber Daya Manusia), 4(2), 172-184.

Purwanto, H., Fauzi, M., Wijayanti, R., Al Awwaly, K. U., \& Jayanto, I. (2020). Developing Model of Halal Food Purchase Intention among Indonesian Non-Muslim Consumers: An Explanatory Sequential Mixed Methods Research. Systematic Reviews in Pharmacy, 11(10), 396-407.

Rawi, R. D. P., \& Aprilia, L. (2019). Mekanisme Pendistribusian Produk Telkomsel Kepada Konsumen Melalui PT Telesindo Shop Di Kota Sorong.

Sugiyono. (2017). Metode Penelitian Kuantitatif, Kualitatif, dan RED, Alfabeta cv: Bandung.

Sunarsi, D. (2020). Pengaruh Bauran Pemasaran Dan Kualitas Pelayanan Terhadap Kepuasan Konsumen Pada Giant Dept Store Cabang BSD Tangerang. E-Mabis: Jurnal Ekonomi Manajemen dan Bisnis, 21(1), 7-13.

Yusuf, A., \& Sunarsi, D. (2020). The Effect of Promotion and Price on Purchase Decisions. Almana: Jurnal Manajemen dan Bisnis, 4(2), 272-279. 